\title{
PENGARUH JOKOWI EFFECT TERHADAP REAKSI SAHAM PERUSAHAAN YANG TERDAFTAR PADA JAKARTA ISLAMIC INDEX
}

\author{
Lalu Muhamad Abdullah \\ Dyah Fitriani \\ Universitas Ahmad Dahlan
}

\begin{abstract}
ABSTRAK
This study examined, abnormalreturn differences, and differences in the volume traded on the stock companies listed on the Jakarta index Islmic Index before and after the announcement of the nomination of events Joko Widodo as President. Population in this research that companies listed on the index JII. Objects in this study is 30 companies. The sampling technique means that all members of the saturated sample or population used as a sample in the study. Data collection techniques with methods of documentation obtained from yahoo finance, IDX. Analysis tools used in this research that Paired samples t-test and One Sample T-test with SPSS 20 software. The test results on the effect of Jokowi effect on the reaction of the company's shares are listed on the index can be concluded there is abnormalreturn JII daily before and after the announcement. However, there were no differences in abnormalreturn and volume of sales before and after the announcement.
\end{abstract}

Keywords: Jokowi Effect, Abnormal Return, Volume Sales

\section{PENDAHULUAN}

Efek Jokowi (Jokowi Effect) merupakan istilah media dalam mendeskripsikan pengaruh kepopuleran Joko Widodo terhadap perpolitikan dan prekonomian di Indonesia. Pencalonan Joko Widodo sebagai calon presiden dalam pemilihan umum presiden Indonesia 2014 diyakini dapat mendongkrak suara Partai Demokrasi Indonesia sampai 30\% sedangkan dalam pasar modal efek Jokowi dikatakan dapat meningkatkan gairah penanam modal karena mempunyai rekam jejak yang pro rakyat dan memiliki rekam jejak yang bersih (Wikipedia, 2014). Suatu peristiwa politik seperti pemilihan presiden dapat mempengaruhi investor untuk berinvestasi sehingga pergerakan pasar di Bursa Efek Indonesia (BEI) menjadi positif. Dengan kondisi atau kinerja politik yang baik maka akan terjadi peningkatan ekonomi suatu Negara. Kondisi politik sangat berpengaruh terhadap hal-hal non ekonomi yang dapat mempengaruhi kelancaran dalam investasi dan stabilitas suatu negara. Faktor-faktor non ekonomi di antaranya adalah pemilihan umum, pemilihan kepala daerah dan bisa juga berasal dari kerusuhan politik yang sangat mempengaruhi respon pelaku pasar sehingga menjadi respon yang negatif (Munari, 2007). Peristiwa terpilihnya Joko Widodo sebagai calon presiden merupakan suatu informasi dan peristiwa politik yang memiliki skala Nasional yang dapat mempengaruhi pergerakan pasar modal. Hari dimana terpilihnya Joko Widodo sebagai calon presiden Indonesia menjadi tranding topic dalam berita nasional maupun berita dalam pasar modal yang bereaksi positif. Berpihaknya pasar 
kepada salah satu calon presiden terlihat ketika peristiwa terpilihnya Joko Widodo sebagai calon presiden. Pada saat sebelum pencalonan presiden Joko Widodo perdagangan saham di IHSG masih berada pada zona merah namun setelah pencalonan presiden Joko Widodo pada tanggal 14 maret 2014 menjelang sore hari perdagangan saham di IHSG mengalamai kenaikan yang sangat signifikan yaitu lebih dari $3 \%$, atau 124 poin menjadi 4.869 di saat penutupan pasar (BBC News, 2014).

Pada tahun 1985 Joko Widodo menyelesaikan kuliahnya di Univesitas Gajah Mada Fakultas Kehutanan. Setelah lulus kemudian Joko Widodo bekerja di sebuah BUMN di Aceh selama 1,5 tahun. Dengan niat dan tekad yang besar Joko Widodo membangun sebuah usaha mebel di kota Solo, setelah tiga tahun berjalan produknya mulai di ekspor. Karir politik Joko Widodo berawal dari walikota Solo. Pada saat mencalonkan diri sebagai walikota Joko Widodo sebelumnya juga masih menjabat sebagai ketua Asmindo periode 2002-2005 yang beranggotakan para pebisnis kayu. Dengan dukungan temantemannya di Asmindo Pada tahun 2005 mulailah Joko Widodo mencalonkan diri sebagai walikota Solo, dan pada akhirnya Joko Widodo terpilih sebagai walikota Solo periode 2005-2010 dan terpilih kembali untuk periode 2010-2015. Sebelum habis masa jabatannya sebagai walikota Solo pada tahun 2012 Joko Widodo kembali mencalonkan diri sebagai Gubernur DKI Jakarta periode 2012-2017. Pada tanggal 14 maret 2014 Joko Widodo kembali mencalonkan diri sebagai presiden Indonesia yang ke 7 (Dunia Baca, 2014).

Dengan meningkatnya harga saham di IHSG pada saat dilantiknya Joko Widodo sebagai presiden membuktikan bahwa harapan pasar terhadap pemerintahan di Indonesia sangat besar. Dengan harapan terpilihnya Joko Widodo sebagai presiden dapat meningkatkan kinerja suatu bangsa dalam hal ekonomi sehingga memberikan return kepada para investor atau pemegang saham. Peran pemerintah yang baik sangat di perlukan dalam sebuah investasi karena dalam hal investasi salah satu faktor yang dapat mempengaruhi harga saham dan investasi ialah kondisi politik, kondisi politik juga memberikan peran dalam membantu peningkatan pertumbuhan ekonomi yang pada akhirnya dapat memberikan pengaruh positif dalam hal permintaan dan penawaran sekuritas.

Studi mengenai event study telah banyak dilakukan. Munari (2004) yang meneliti tentang reaksi pasar setelah hasil pemilu 2004, dimana diperoleh hasil penelitian bahwasanya abnorma lreturn dan trading volume activity tidak berpengaruh signifikan terhadap peristiwa terpilihnya SBY sebagai presiden RI. pada peristiwa ini bahwasanya merupakan peristiwa yang murni politik dengan sekala nasional, akan tetapi pasar tidak merespon positif terhadap peristiwa terpilihnya SBY sebagai presiden.

Penelitian yang berkaitan dengan event studies pernah juga di teliti oleh Rakhmawati dan Fitriani (2012), yang meneliti tentang reaksi pasar saham terhadap pengumuman perubahan peringkat obligasi pada perusahaan yang terdaftar di Bursa Efek Indonesia dimana pada penelitian tersebut di peroleh kesimpulan bahwasanya pengumuman perubahan peringkat obligasi pada perusahaan yang terdapat di Bursa Efek Indonesia tidak berpengaruh terhadap pasar saham baik itu penurunan ataupun kenaikan, peneliti menjelasakan bahwasanya informasi yang berkaitan tentang kenaikan peringkat obligasi hanya sebatas informasi pelengkap. Karena pengumuman peringkat obligasi tidak dapat memberikan jaminan kinerja perusahaan di tahun berikutnya.

Penelitian ini akan menguji mengenai seberapa pengaruh Jokowi effect terhadap reaksi saham pada perusahaan yang terdaftar di JII. 


\section{REVIEW LITERATUR DAN HIPOTESIS}

\section{Efisiensi Pasar}

Pasar yang efisen ialah pasar yang dimana harga semua sekuritas yang diperdagangkan mencerminkan semua informasi yang tersedia. Berkaitan dengan informasi tersebut informasi yang tersedia berupa informasi masa lalu yaitu laba prusahaan tahun lalu, maupun informasi saat ini yaitu pembagian deviden tahun ini, Informasi yang digunakan juga dapat bersifat sebagai pendapat atau opini yang rasional dan dapat mempengaruhi perubahan harga saham (Tandelilin, 2010).

Menurut Fama dalam Tandelilin (2010), menyajikan informasi efisiensi pasar ke dalam tiga bagian yaitu:

\section{a. Efisiensi dalam betuk lemah (weak form)}

Efisiensi pasar dalam bentuk ini ialah mengukur sejauh mana informasi masa lalu mempengaruhi harga sekuritas pada saat ini. Informasi yang digunakan dalam bentuk lemah ialah informasi atau peristiwa masa lalu.

b. Efisiensi dalam bentuk setengah kuat (semi strong)

Efisiensi pasar dalam bentuk ini ialah mengukur sejauh mana informasi masa lalu dan informasi yang di publikasikan saat ini dapat mempengaruhi harga sekuritas pada waktu atau hari seputar pengumuman informasi tersebut, dalam bentuk ini return tak normal hanya terjadi pada saat pengumuman suatu peristiwa sebagai respon terhadap peristiwa tersebut. Informasi yang digunakan ialah informasi masa lalu dan informasi yang di publikasikan saat ini yaitu berupa earning, deviden, stock split, penerbitan saham baru dan peristiwa yang terpublikasikan lainnya. c. Efisiensi dalam bentuk kuat (strong form)

Efisiensi pasar dalam bentuk ini mengukur sejauh mana informasi masa lalu, informasi yang di publikasikan saat ini dan informasi yang tidak di publikasikan perusahaan dapat mempengaruhi harga sekuritas. Pada efisiensi pasar dalam bentuk ini para investor tidak akan memperoleh return tak normal (Tandelilin, 2010).

\section{Studi Peristiwa (Event Studies)}

Event studies merupakan penelitian yang berkaitan tentang seberapa cepat kandungan informasi yang masuk ke pasar dapat mempengaruhi harga saham (Tandelilin, 2010), sedangkan menurut Jogiyanto (2000) menyatakan bahwa event studies mengukur sejauh mana hubungan antara suatu peristiwa yang mempengaruhi surat berharga dan return yang diterima oleh investor.

\section{Abnormal Return dan Expected Return}

Setiap investasi yang dilakukan oleh para investor baik investasi jangka panjang ataupun investasi jangka pendek investor selalu mengharapkan keuntungan (expected return) atas investasi yang telah dilakukan tersebut. Dengan adanya expected return tersebut keinginan investor untuk melakukan investasi semakin tinggi apabila tidak mendapatkan expected return tentunya investor tidak akan memiliki ketertarikan dalam berinvestasi. Menurut Jogiyanto (2000), abnormal return merupakan selisih pengembalian return yang lebih tinggi dari return yang di harapkan oleh investor.

\section{Aktivitas Volume Perdagangan}

Dalam aktifitas perdagangan di pasar modal, volume perdagangan merupakan suatu elemen yang menjadi salah satu bahan untuk melihat reaksi pasti terhadap sebuah informasi yang masuk ke dalam pasar. TVA (Tranding 
Volume Activity) adalah perbandingan jumlah saham yang ditransaksikan waktu tertentu dengan jumlah saham yang beredar pada waktu yang sama. Semakin tinggi nilai aktivitas volume perdagangan menunjukkan semakin banyak lembar saham yang beredar dalam pasar.

\section{METODE PENELITIAN \\ Objek Penelitian \\ Objek dalam penelitian ini adalah JII (Jakarta Islamic Index). Sedangkan populasi dalam penelitian ini adalah 30 perusahaan yang termasuk dalam indeks JII periode 1 Desember 2013 sampai dengan 31 Mei 2014 dan terdaftar di Bursa Efek Indonesia. \\ Jenis data dan Sumber data \\ Jenis data yang digunakan dalam penelitin ini adalah data sekunder, yaitu data yang diperoleh secara tidak langsung, berupa data harga saham dan volume perdagangan. Sumber data diperoleh dari Yahoo Finance dan IDX (Indonesian Stock Exchange).}

\section{Teknik Pengumpulan Data}

Teknik pengumpulan data dalam penelitian ini adalah dengan metode dokumentasi yang diperoleh dari Yahoo Finance dan IDX (Indonesian Stock Exchange). Selain itu pengumpulan data dilakukan dengan menggunakan studi pustaka pada buku-buku literatur dan referensi jurnal keuangan.

\section{HASIL PENELITIAN DAN PEMBAHASAN}

\section{Uji Normalitas}

Berdasarkan pengujian normalitas $a b$ normal return harian menggunakan KolmogorofSmirnov diperoleh hasil sebagai berikut:
Tabel 1

Uji Normalitas Abnormal Return Harian

\begin{tabular}{|c|c|c|}
\hline Hari & Sign & Keterangan \\
\hline-10 & 0,905 & Normal \\
\hline-9 & 0,935 & Normal \\
\hline-8 & 0,386 & Normal \\
\hline-7 & 0,033 & Tidak Normal \\
\hline-6 & 0,103 & Normal \\
\hline-5 & 0,142 & Normal \\
\hline-4 & 0,713 & Normal \\
\hline-3 & 0,769 & Normal \\
\hline-2 & 0,934 & Normal \\
\hline-1 & 0,796 & Normal \\
\hline 0 & 0,966 & Normal \\
\hline 1 & 0,628 & Normal \\
\hline 2 & 0,750 & Normal \\
\hline 3 & 0,567 & Normal \\
\hline 4 & 0,855 & Normal \\
\hline 5 & 0,474 & Normal \\
\hline 6 & 0,897 & Normal \\
\hline 7 & 0,482 & Normal \\
\hline 8 & 0,821 & Normal \\
\hline 9 & 0,214 & Normal \\
\hline 10 & 0,334 & Normal \\
\hline
\end{tabular}

Sumber: Data diolah, 2014

Dari tabel di atas terlihat bahwa hanya ada satu hari (H-7) yang tidak normal, sehingga dapat dideskripsikan normal karena jumlah data yang normal lebih banyak dari yang tidak normal.

Berdasarkan pengujian normalitas abnormal return sebelum dan sesudah, menggunakan Kolmogorof-Smirnov diperoleh hasil sebagai berikut:

Tabel 2

Uji Normalitas Abnormal Return SebelumSesudah

\begin{tabular}{|c|c|c|}
\hline Hari & Sig & Keterangan \\
\hline Sebelum & 0,992 & Normal \\
\hline Sesudah & 0,649 & Normal \\
\hline
\end{tabular}

Sumber: Data diolah, 2014 
Terlihat pada tabel di atas baik sebelum maupun setelah peristiwa pengumuman masingmasing data berdistribusi normal, dibuktikan dengan nilai sig. yang lebih besar dari alpha $5 \%$.

Berdasarkan pengujian normalitas volume aktivitas penjualan menggunakan Kolmogorof Smirnov diperoleh hasil sebagai berikut:

Tabel 3

Hasil Uji Normalitas Volume Aktivitas Sebelum-Sesudah

\begin{tabular}{|c|c|c|}
\hline Hari & Sig & Keterangan \\
\hline Sebelum & 0,806 & Normal \\
\hline Sesudah & 0,684 & Normal \\
\hline
\end{tabular}

Sumber: Data diolah, 2014

Terlihat pada tabel di atas baik sebelum maupun setelah peristiwa pengumuman masingmasing data berdistribusi normal, dibuktikan dengan nilai sig. yang lebih besar dari alpha $5 \%$.

\section{Uji Hipotesis}

Berdasarkan pengujian abnormal return harian menggunakan one sample test diperoleh hasil sebagai berikut:

Tabel 4

Uji Abnormal Return Harian

\begin{tabular}{|r|c|l|}
\hline Hari & Sign & Keterangan \\
\hline-10 & 0,329 & Tidak Signifikan \\
\hline-9 & 0,931 & Tidak Signifikan \\
\hline-8 & $0,042^{*}$ & Signifikan \\
\hline-7 & 0,897 & Tidak Signifikan \\
\hline-6 & 0,326 & Tidak Signifikan \\
\hline-5 & 0,283 & Tidak Signifikan \\
\hline-4 & 0,604 & Tidak Signifikan \\
\hline-3 & 0,271 & Tidak Signifikan \\
\hline-2 & 0,167 & Tidak Signifikan \\
\hline-1 & $0,079 * *$ & Tidak Signifikan \\
\hline 0 & $0,063 * *$ & Tidak Signifikan \\
\hline 1 & $0,072 * *$ & Tidak Signifikan \\
\hline
\end{tabular}

\begin{tabular}{|r|c|l|}
\hline 2 & $0,095^{* *}$ & Tidak Signifikan \\
\hline 3 & 0,901 & Tidak Signifikan \\
\hline 4 & 0,854 & Tidak Signifikan \\
\hline 5 & 0,111 & Tidak Signifikan \\
\hline 6 & 0,829 & Tidak Signifikan \\
\hline 7 & 0,409 & Tidak Signifikan \\
\hline 8 & 0,903 & Tidak Signifikan \\
\hline 9 & 0,831 & Tidak Signifikan \\
\hline 10 & $0,043^{*}$ & Signifikan \\
\hline
\end{tabular}

Sumber: Data diolah, 2014

Dari hasil pengujian abnormal return harian dengan alpha 5\% terlihat abnormal return terjadi pada $\mathrm{H}-8$ dan $\mathrm{H}+10$. Akan tetapi apabila menggunakan alpha $10 \%$, abnormal return terjadi pada $\mathrm{H}-8, \mathrm{H}-1, \mathrm{H} 0, \mathrm{H}+1, \mathrm{H}+2$ dan $\mathrm{H}+10$.

Berdasarkan pengujian Abnormal Return sebelum dan sesudah peristiwa menggunakan Paired Sample T-test diperoleh hasil sebagai berikut:

\section{Tabel 5}

Uji Beda Abnormal Return Sebelum-Sesudah

\begin{tabular}{|c|c|c|}
\hline Hari & Sig. & Keterangan \\
\hline $\begin{array}{c}\text { Sebelum- } \\
\text { Sesudah }\end{array}$ & 0,848 & $\begin{array}{c}\text { Tidak } \\
\text { Signifikan }\end{array}$ \\
\hline
\end{tabular}

Sumber: Data diolah, 2014

Dari hasil pengujian di atas diperoleh hasil signifikansi pada JII sebesar 0,848 hal ini menunjukkan bahwa sign $>$ alpha $(0,848>0,05)$ maka terima H0. Dengan demikian dapat ditarik kesimpulan bahwa tidak terdapat perbedaan abnormal return pada saham perusahaan yang terdaftar pada indeks JII sebelum dan setelah pengumuman pencalonan Joko Widodo sebagai presiden RI periode.

Berdasarkan pengujian volume penjualan menggunakan Paired Sample T-test diperoleh hasil sebagai berikut: 
Tabel 6

Uji Beda Volume Penjualan

Sebelum-sesudah

\begin{tabular}{|l|l|l|}
\hline Hari & Sig. & Keterangan \\
\hline SEBELUM-SESUDAH & 0,648 & Tidak Signifikan \\
\hline
\end{tabular}

Sumber: Data diolah, 2014

Dari hasil pengujian tersebut dapat dilihat bahwa nilai sign $>$ alpha $(0,648>0,05)$. Dari hasil tersebut dapat ditarik kesimpulan bahwa tidak ada perbedaan jumlah transaksi atau volume transaksi pada saat sebelum dan sesudah pencalonan Joko Widodo sebagai presiden RI.

\section{KESIMPULAN DAN SARAN}

Dari hasil analisis data yang telah dilakukan dapat ditarik kesimpulan bahwa tidak terdapat abnormal return harian yang signifikan pada saham perusahaan yang terdaftar pada indeks Jakarta Islamic Index (JII) selama periode peristiwa. Abnormal return dengan tingkat alpha $5 \%$ hanya terjadi pada hari ke $\mathrm{H}-8$ dan $\mathrm{H}+10$. Akan tetapi apabila menggunakan alpha $10 \%$, abnormal return terjadi pada $\mathrm{H}-8, \mathrm{H}-1, \mathrm{H} 0, \mathrm{H}+1$, $\mathrm{H}+2$ dan $\mathrm{H}+10$.

Tidak terdapat perbedaan abnormal return saham perusahaan yang terdaftar pada JII (Jakarta Islamic Index) sebelum dan sesudah peristiwa pencalonan Joko Widodo sebagai presiden, hal ini dibuktikan dengan hasil analisis menggunakan paired sampel T-test dengan membandingkan tingkat signifikan dengan alpha $(0,848>0,05)$.

Tidak terdapat perbedaan volume saham yang ditransaksikan pada perusahaan yang terdaftar di JII (Jakarta Islamic Index) sebelum dan sesudah peristiwa pencalonan Joko Widodo sebagai presiden, hal ini dibuktikan dengan hasil analisis menggunakan paired sampel T-test dengan membandingkan tingkat signifikan dengan alpha $(0,648>0,05)$.

Saran untuk para peneliti yang akan datang adalah peneliti berikutnya tidak hanya menggunakan indeks JII (Jakarta Islamic Index) saja untuk melihat adanya pengaruh pencalonan presiden terhadap abnormal return akan tetapi bisa juga menggunakan indeks yang lain. Peneliti selanjutnya juga diharapkan menggunakan estimasi return dengan model lainya yaitu mean adjusted model dan market model, selain itu juga dapat memasukkan pengumuman dan factorfactor lain yang dapat mempengaruhi abnormal return seperti stock split, merger, right issue, deviden atau yang lainya.

Untuk para investor apabila terjadi hal sama di harapkan investor untuk menunggu dan melihat kinerja dari pemerintah baru tersebut sebelum melakukan investasi, karena calon presiden belum bisa memberikan kontribusi dan kebijakan yang dapat meningkatkan return bagi investor

\section{DAFTAR PUSTAKA}

Hartono, Jogiyanto M. 2003. Teori Portofolio dan Analisis Investasi. Cetakan Pertama Yogyakarta: BPFE.

Hartono, Jogiyanto M. 2004. Metodologi Penelitian Bisnis. Cetakan Pertama. Yogyakarata: BPFE.

Munari. 2007. " Reaksi Pasar Setelah Hasil Pemilu 2004 " Journal Riset Ekonomi dan Bisnis, Vol 7, hal 58-69.

Nugroho, Setiawan, Bayu. 2012. Analisis Pengaruh Suku Bunga Deposito, Inflasi, dan Kurs terhadap Harga Saham pada Indutri Perbankan di BEJ, Skripsi. Yogyakarta: Universitas Ahmad Dahlan

Rakhmawati, Melilia dan Fitriyani, Dyah. 2012. Reaksi Pasar Saham Terhadap Pengumuman Perubahan Pengingkat Obligasi Pada Perusahaan Yang terdaftar di Bursa efek Indonesia. Fokus, Vol. 1, hal 1-8.

Sugiyono, 2008. Metoda Penelitian Bisnis. Cetakan Keduabelas. Bandung: Alfabeta 
Sunariah. 2003. Pengantar Pengetahuan Pasar Modal. Edisi Ketiga. Yogyakarta: AMP YKPN.

Tandelilin, Eduardus. 2010. Portofolio dan Investasi. Edisi pertama. Yogyakarta: Kanisius.

Zarina. 2011. Analisis Perbedaan Harga dan Volume Perdagangan Saham Sebelum dan Sesudah Tanggal Pengumuman Deviden pada Perusahaan Publik di Indonesia, Skripsi. Yogyakarta: Universitas Ahmad Dahlan.

http://www.bbc.co.uk/indonesia/berita indonesia/2014/04/140409_ekonomi pileg.shtml. [Di Akses tanggal 8 september 2014] http://arsip.bewara.co/read/2014/03/reaksipasar-dan-euforia-jokowi

[Di akses tanggal 8 september 2014] http://duniabaca.com/profile-joko-widodo.html [Di akses tanggal 22 september 2014] http://ejournal.upnjatim.ac.id/index. php/rebis/article/view/59 [Di akses tanggal 7 september 2014]

http://id.wikipedia.org/wiki/Efek Jokowi

[Di akses tanggal 7 November 2014]

http://finance.yahoo.com/

[Di akses tanggal 7 November 2014] 